\title{
Sulfuric Acid Leaching of Heavy Rare Earth Elements (HREEs) from Indonesian Zircon Tailing
}

\author{
Iga Trisnawati ${ }^{1,2}$, Gyan Prameswara ${ }^{1}$, Panut Mulyono ${ }^{1}$, Agus Prasetya ${ }^{1,3}$, \\ Himawan Tri Bayu Murti Petrus $13^{*}$ \\ ${ }^{1}$ Sustainable Mineral Processing Research Group, Department of Chemical Engineering, Faculty of \\ Engineering, Universitas Gadjah Mada, Jl. Grafika No.2, Yogyakarta 55281, Indonesia \\ ${ }^{2}$ Center for Accelerator Science and Technology, National Nuclear Energy Agency, Jl. Babarsari Kotak Pos \\ 6101, Yogyakarta 55281, Indonesia \\ ${ }^{3}$ Unconventional Georesources Research Center, Faculty of Engineering, Universitas Gadjah Mada, Jl. Grafika \\ No.2, Yogyakarta 55281, Indonesia
}

\begin{abstract}
Solid pollution has been an issue in mineral processing for decade. One of these pollutants is zircon sand mining waste (zircon tailing). Due to the concentration of rare earth minerals in zircon tailing and the increasing demand of REE in advanced technologies, studying zircon tailing as a potential source of REE had become an interest for us. Our experiments consisted of mineral characterization and an alkaline fusion process, followed by a leaching process. The characterization process was carried out to obtain actual information from zircon tailing samples. This process showed total rare earth elements (REEs) content of 58.62\%, at 9\%, 1\%, 1.2\%, 1.7\%, and $1.5 \%$ for $Y, \mathrm{Gd}, \mathrm{Er}$, Dy, and $\mathrm{Yb}$, respectively. A sieving process was carried out since it was known that most heavy rare earth elements (HREEs) content occurs at a larger size. The alkaline fusion process was applied with an intent to break the phosphate bonds present in the REE-carrying minerals (xenotime and monazite) and convert phosphate bonds to hydroxide bonds in rare earth metals. During the alkaline fusion process, as much as $75 \%, 66.45 \%$, and $60 \%$ of the phosphate, silica, and zirconium, respectively, were reduced. The leaching process was carried out in a flatbottom three-neck flask. The optimum point of leaching experiments occurs at $0.5 \mathrm{M} \mathrm{H}_{2} \mathrm{SO}_{4}, 60^{\circ} \mathrm{C}$, and a solid-to-liquid (S/L) ratio of $10 \mathrm{~g} / 100 \mathrm{~mL}$. In these conditions, as much as $89 \%, 99 \%, 94 \%$, $92 \%$, and $90 \%$ of $\mathrm{Y}, \mathrm{Gd}, \mathrm{Er}$, Dy, and $\mathrm{Yb}$, respectively, were recovered as an HREEs ${ }_{2}-\left(\mathrm{SO}_{4}\right)_{3}$ product solution.
\end{abstract}

Keywords: Acid leaching; Alkaline fusion; Rare earth elements; Zircon tailing

\section{Introduction}

The issue of decreasing environmental quality has been an increasing concern recently (Hudson-Edwards and Dold, 2015; Kusrini et al., 2018a, 2018b; Reichl et al., 2018). All fields are affected by this problem - the mining sector included, which leaves waste as a result of mining activities (Durucan et al., 2006; Aznar-Sánchez et al., 2018). This waste has not been treated to reduce environmental pollution, such as tailings from the zircon mining in Indonesia. This tailing waste contains several important elements that are useful for advanced technology and can potentially be extracted from mining waste treatment. Some of these elements are "heavy rare earth elements" (HREEs) (Harjanto et al., 2013, Hamzah

*Corresponding author's email: bayupetrus@ugm.ac.id, Tel.: +62-22-2508124

doi: 10.14716/ijtech.v11i4.4037 
et al., 2018).

Rare earth elements (REEs) are all elements in lanthanides, totaling 17 elements, including scandium and yttrium. The REEs are divided into two groups, based on atomic weight: the light rare earth elements, which are lanthanum through europium (atomic numbers 57-63), and the heavy rare earth elements, which are gadolinium through lutetium (atomic numbers 64-71). Yttrium (atomic number 39), though light, is included among the heavy REEs group due to its common chemical and physical affiliations with the heavy REEs in nature (Qi, 2018). These elements have chemical and physical properties in common, and they are useful for many advanced technologies, such as superconductors, magnets, and catalysts (Habashi, 1992; Gupta and Krishnamurthy, 2005; Kusrini et al., 2018a; Machmudah et al., 2019). Usually, the separation process cannot be carried out directly to obtain oxides or pure elements from rare earth minerals due to their similarity (El Hady et al., 2016; Kusrini et al., 2018b).

The existence of rare earth metals (REMs) is not as rare as their name suggests. The presence of cerium (Ce), praseodymium (Pr), samarium ( $\mathrm{Sm}$ ), and Yttrium (Y) is even more extensive than precious metals (gold [Au], silver [Ag], and platinum [Pt]) in the earth's crust (Lide, 2004). Even at the end of 2018, rare earth oxide production reached more than 150,000 metric tons, but its occurrence in mineable deposits is limited (King, 2013; Haxel et al., 2014; Gambogi, 2019). Therefore, to meet the increasing global demand for REMs, efficient extraction technology from secondary sources is needed.

There are several ways to extract rare earth metals from their carrier minerals, such as direct leaching using sulfuric acid at temperatures of $155-230^{\circ} \mathrm{C}$, alkali cracking using a sodium hydroxide solution at $140^{\circ} \mathrm{C}$, roasting using sodium carbonate at $900^{\circ} \mathrm{C}$, and alkaline fusion using flakes of sodium hydroxide at $400-500^{\circ} \mathrm{C}$. The disadvantages of the above extraction processes are: (1) for the direct leaching process using sulfuric acid, the formation of REE double sulfate cannot be avoided, so it will affect the refining process of REEs, and during this process, the phosphate that binds to the monazite cannot be separated immediately; (2) consumption of sodium hydroxide is too high in the cracking process using sodium hydroxide (REE / $\mathrm{NaOH}=1 / 21$ ); and (3) high energy requirements are prohibitive in the roasting process using sodium carbonate (Sadri et al., 2017). Another process for extracting rare earth elements is the alkaline fusion process. This process is carried out by reacting rare earth minerals with alkali in order to get $\mathrm{REE}-(\mathrm{OH})_{3}$, while the phosphate turns into a $\mathrm{Na}_{3} \mathrm{PO}_{4}$ byproduct. The two products can be separated by washing them with water. REE- $(\mathrm{OH})_{3}$ remains in the solid phase while $\mathrm{Na}_{3} \mathrm{PO}_{4}$ dissolves. The alkaline fusion process was chosen for our experiments because it offers several advantages. The main advantage is that the alkaline fusion process can break the phosphate bonds in xenotime and monazite and break the silica matrix to make the leaching process more effective (Biswas et al., 2010; Dai et al., 2014; Tang et al., 2019). Furthermore, rare earth hydroxide (REE- $[\mathrm{OH}]_{3}$ ) products easily occur through this process. Another advantage is that $\mathrm{Na}_{3} \mathrm{PO}_{4}$ can be purified as a byproduct. These conditions are needed to enhance the effectiveness of leaching. The leaching process is performed to dissolve the rare earth element, which ensues at a $\mathrm{pH}$ below 3.5 (Amer et al., 2013; Kumari et al., 2015).

In this experiment, HREEs were extracted from Indonesian zircon tailings. The purpose of this research was to determine the optimum conditions for the leaching of HREEs from alkaline fusion products (HREEs- $[\mathrm{OH}]_{3}$ ). Pretreatment was carried out through an alkaline fusion process to break the phosphate bonds in HREE (monazite and xenotime) carrier minerals. Then, the leaching process was carried out using sulfuric acid under various leaching conditions. 


\section{Methods}

\subsection{Materials and Sample Preparation}

Samples were obtained from zircon sand mining operations on Bangka Island and in Central Borneo, Indonesia. The extracted tailings were byproducts of the magnetic separation process (Priyono and Febrianto, 2012). The zircon tailings used for this experimental purpose were the same sample used previously by our group to extract REMs (Prameswara et al., 2019, 2020). The representative portions of the sample used for different tests were obtained by a cone-and-quartering method of sampling (Febriana et al., 2018). To determine the REEs' composition, the samples were analyzed using XRF (Malvern Panalitycal, Epsilon 4), and the analyses were repeated three times. The sample was then sieved to collect various-size fractions. A Vibratory Sieve Shaker AS 200 Basic was used for sifting with a dry process, $500 \mathrm{~g}$ of tailings were sifted three times in repetition with each runtime of 30 minutes. The P80, P50, and P10 of the particles were determined by plotting the aperture size and cumulative undersize. Each tailing size was then analyzed using XRF (Malvern Panalitycal, Epsilon 4) to obtain the concentration of each HREE in each size of the tailings.

\subsection{Alkaline Fusion Process}

A total of $250 \mathrm{~g}$ of tailings samples with a particle size of $-250+125 \mu \mathrm{m}$ was mixed with $\mathrm{NaOH}$ flakes with a mass ratio of 1:1 into a $500 \mathrm{~mL}$ ceramic crucible container. The alkaline fusion process was carried out in a muffle furnace at $450^{\circ} \mathrm{C}$ for three hours. A total of $50 \mathrm{~g}$ of sludge product was then dissolved with $500 \mathrm{~mL}$ of deionized water at $80^{\circ} \mathrm{C}$ for one hour. The dissolution process was carried out in 1,000 mL beaker glass containers equipped with electric heaters and magnetic stirrers. The stirring speed was fixed at $150 \mathrm{rpm}$. The dissolution process product was then separated using vacuum filtration, and the residue (solid) was dried in the oven at $100^{\circ} \mathrm{C}$. This sample was analyzed using XRF (Malvern Panalitycal, Epsilon 4) to obtain the concentration of the HREEs and then fed into the leaching process.

\subsection{Leaching Process}

The leaching process was carried out in a $250 \mathrm{~mL}$ flat-bottom three-neck flask equipped with a condenser and a thermometer. The heating process was carried out with an electric heater equipped with a magnetic stirrer, while the stirring speed and time were fixed at $150 \mathrm{rpm}$ and $60 \mathrm{~min}$, respectively (Trinopiawan et al., 2016). In this experiment, the effects of sulfuric acid $(\mathrm{M})$, temperature $\left({ }^{\circ} \mathrm{C}\right)$, and the solid-to-liquid $(\mathrm{S} / \mathrm{L} ; \mathrm{g} / \mathrm{mL})$ ratios were observed in the recovery of the HREEs. Operating conditions were varied to determine optimum recovery. The leaching experiment matrix is shown in Table 1 and Figure 1.

The optimum point of some leaching conditions was determined by first guessing the initial conditions for the leaching process (an $80^{\circ} \mathrm{C}$ leaching temperature and an S/L ratio of $10 \mathrm{~g} / 100 \mathrm{~mL}$ ). A total $5 \mathrm{~g}$ of rare earth hydroxides (REHs), the product of alkaline fusion, was put into a flat-bottom three-flask neck together with $50 \mathrm{~mL}$ of sulfuric acid solution. The stirring and heating processes were carried out using a magnetic stirrer and an electric heater. Leaching time was calculated after the target temperature $\left(80^{\circ} \mathrm{C}\right)$ had been reached. Then, the product was separated using vacuum filtration, and the solid was dried in an oven at $100^{\circ} \mathrm{C}$.

Solid products were analyzed using XRF (Malvern Panalitycal, Epsilon 4) to determine the remaining HREEs' concentrations in the solid products. XRD (Malvern Panalitycal, Aeris Research DY 844) analysis was also carried out to determine the compounds in solid products. Analysis was performed on three samples, namely: leaching feed, C1 $0.125 \mathrm{M}$ 
$\left.\mathrm{H}_{2} \mathrm{SO}_{4}, \mathrm{~T}=80{ }^{\circ} \mathrm{C}, \mathrm{S} / \mathrm{L}=5 \mathrm{~g} / 50 \mathrm{~mL}, \mathrm{t}=60 \mathrm{~min}, 150 \mathrm{rpm}\right)$, and $\mathrm{C} 5\left(2 \mathrm{M} \mathrm{H}_{2} \mathrm{SO}_{4}, \mathrm{~T}=80{ }^{\circ} \mathrm{C}, \mathrm{S} / \mathrm{L}\right.$ $=5 \mathrm{~g} / 50 \mathrm{~mL}, \mathrm{t}=60 \mathrm{~min}, 150 \mathrm{rpm}$ ). The recovery (\%) was determined based on Equation 1 .

Table 1 Experiment matrix

\begin{tabular}{cccc}
\hline Run No. & $\begin{array}{c}\mathrm{H}_{2} \mathrm{SO}_{4} \text { Concentration } \\
(\mathrm{M})\end{array}$ & $\begin{array}{c}\text { Leaching Temperature } \\
\left({ }^{\circ} \mathrm{C}\right)\end{array}$ & $\begin{array}{c}\text { S/L Ratio } \\
(\mathrm{g} / 100 \mathrm{~mL})\end{array}$ \\
\hline 1 & 0.125 & 80 & 10 \\
2 & 0.25 & 80 & 10 \\
3 & 0.5 & 80 & 10 \\
4 & 1 & 80 & 10 \\
5 & 2 & 80 & 10 \\
6 & 0.5 & 30 & 10 \\
7 & 0.5 & 40 & 10 \\
8 & 0.5 & 60 & 10 \\
9 & 0.5 & 100 & 10 \\
10 & 0.5 & 110 & 10 \\
11 & 0.5 & 60 & 5 \\
12 & 0.5 & 60 & 10 \\
13 & 0.5 & 60 & 15 \\
14 & 0.5 & 60 & 20 \\
15 & 0.5 & 60 & 25 \\
\hline
\end{tabular}

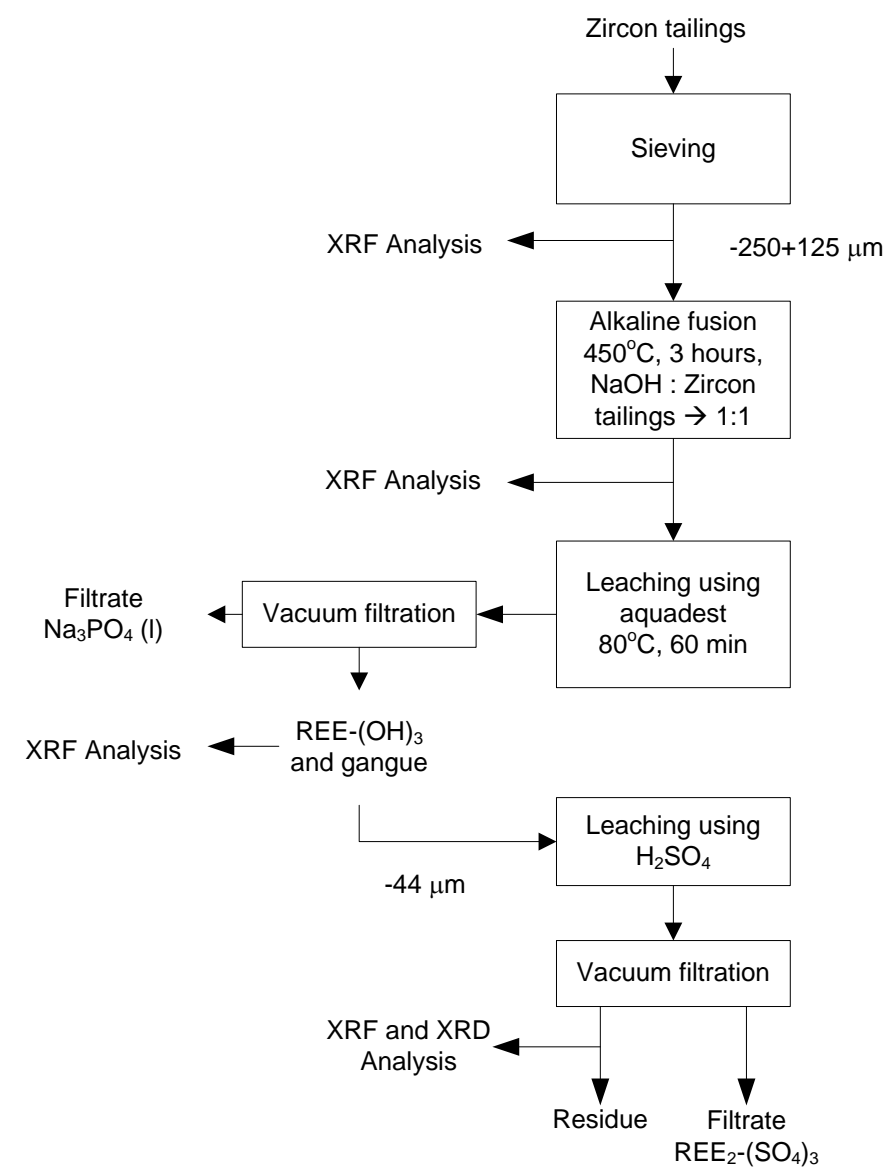

Figure 1 Block diagram of the HREEs leaching procedure from tailing zircon

$$
\operatorname{HREES} \text { recovery }(\%)=\frac{X_{0} \cdot m_{0}-X_{i} \cdot m_{i}}{X_{0} \cdot m_{0}} \times 100 \%
$$


where, $X_{0}$ is the concentration of HREEs in the feed (\%), $m_{0}$ is the initial mass ( $\mathrm{g}$ ), $X_{i}$ is the concentration of HREEs in the solid product of the leaching process (\%), and $m_{i}$ is the mass of solid product after the leaching process $(\mathrm{g})$.

\section{Results and Discussion}

\subsection{Mineral Characterization}

The sifting process was carried out to determine the mass fraction of each tailing size. Sieves varied in size from 600 to $44 \mu \mathrm{m}$. The tailings size analysis is presented in Table 2 .

Table 2 Tailing size analysis

\begin{tabular}{cccccc}
\hline $\begin{array}{c}\text { Sieve size range } \\
(\mu \mathrm{m})\end{array}$ & $\begin{array}{c}\text { Nominal aperture } \\
\text { size }(\mu \mathrm{m})\end{array}$ & wt $(\mathrm{g})$ & wt $(\%)$ & $\begin{array}{c}\text { Total REMs } \\
(\%)\end{array}$ & $\begin{array}{c}\text { Cumulative } \\
\text { undersize }(\%)\end{array}$ \\
\hline$-600+425$ & 425 & 0 & 0.00 & - & 100 \\
$-425+250$ & 250 & 20.77 & 1.38 & 64 & 98.62 \\
$-250+125$ & 125 & 824.12 & 54.94 & 58 & 43.674 \\
$-125+44$ & 44 & 653.3 & 43.55 & 51 & 0.12 \\
-44 & & 1.81 & 0.12 & 41 & \\
\hline Total & 1500 & 100 & & \\
\hline
\end{tabular}

Table 1 shows that the REMs' concentration in zircon tailing accumulated higher at larger particle sizes. The highest mass fraction was observed in the $-250+125 \mu \mathrm{m}$ of tailing particle size, and about $55 \%$ of the total mass accumulated at this particle size range, while about $44 \%$ of the mass fraction accumulated in the particle size range of $-125+44 \mu \mathrm{m}$. Some studies have shown that sieving can be a method to classify and concentrate both milled and natural weathered minerals, as shown in the studies of rare earth metals concentration using sieving from secondary resources (Eduafo, 2013). Mineralogical analyses by AIST stated that the grinding size for REE beneficiation would be around $80 \%$, passing in a particle size of 50-100 $\mu \mathrm{m}$ (Yang et al., 2015). Another reference stated that the liberation of REE-bearing minerals was at $\mathrm{P}_{90}=120.47 \mu \mathrm{m}$ (Brückner et al., 2020). Referring to the fine size of zircon tailing $\left(\mathrm{P}_{80}=120.11 \mu \mathrm{m}, \mathrm{P}_{50}=109.8 \mu \mathrm{m}, \mathrm{P}_{10}=51.03 \mu \mathrm{m}\right)$ as well as the sieving results shown in Table 1, milling was not conducted in this experiment in order to minimize the energy consumption of the process. The $-250+125 \mu \mathrm{m}$ tailing size was chosen as an alkaline fusion feed because it has the highest mass fraction and the total rare earth element content exceeds $50 \%$ of the sample. Moreover, it was selected due to the highest presence of yttrium and gadolinium at $8.8 \%$ and $0.756 \%$, respectively (as shown in Figure 2). The fine sample size also provided convenience in subsequent processes (alkali fusion and leaching using sulfuric acid), providing an appropriate surface area for the optimum reaction to occur (Brückner et al., 2020; Handoko and Sanjaya, 2018). 


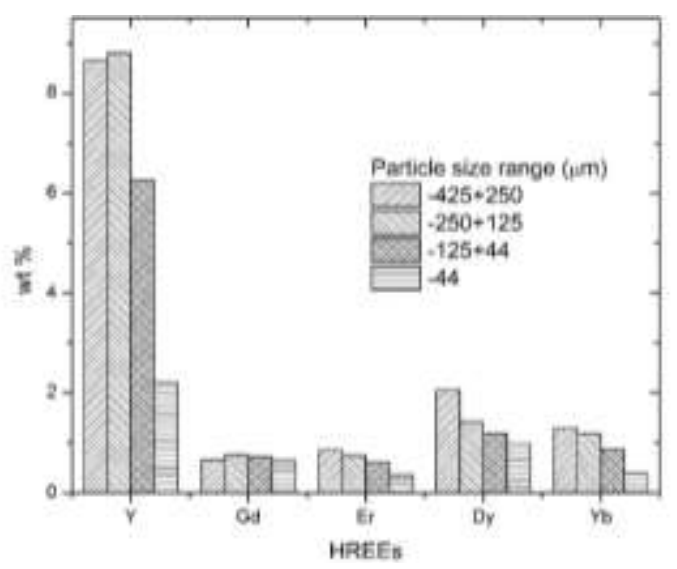

Figure 2 HREEs content at various particle sizes

Figure 3 shows that rare earth elements are the major element found in tailings, at $58.62 \%$. These rare earth elements accumulated in larger particle sizes. HREEs-bearing minerals were known to be monazite and xenotime, which contain cerium, lanthanum, and yttrium in high concentrations (Figure 3).
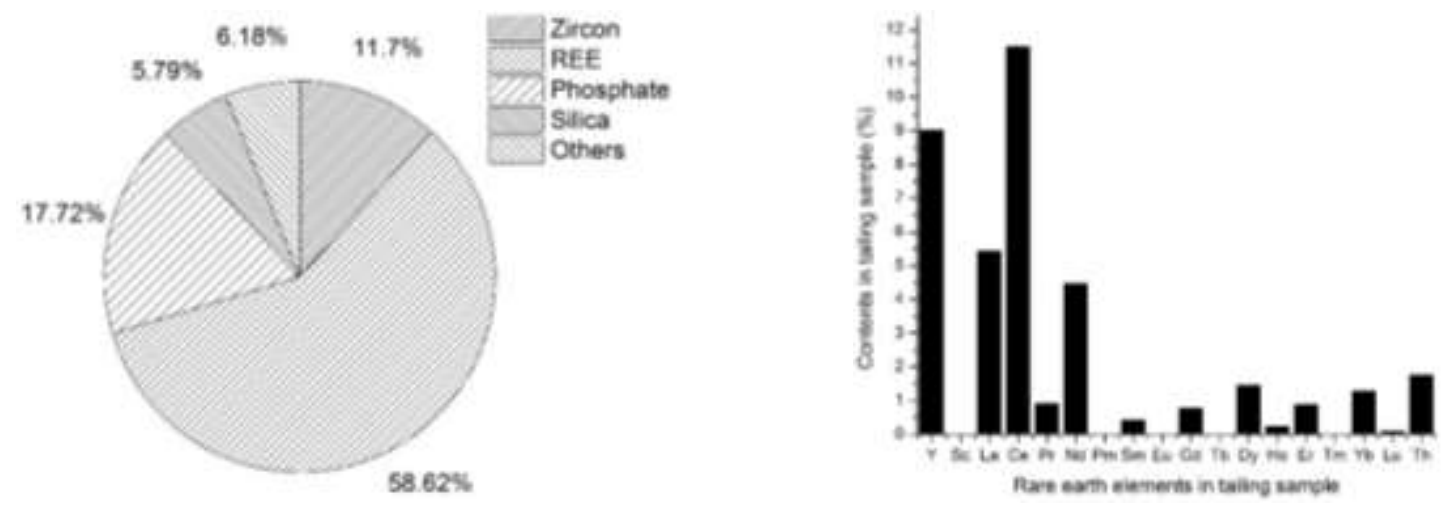

Figure 3 Major element content in the tailing sample

\subsection{Alkaline Fusion}

For a better recovery of HREE leaching, an alkaline fusion process was carried out to break the phosphate bonds in monazite and xenotime. The reaction that occurs in this process is shown in Equations 2-7 (Beyer et al., 1954; Biswas et al., 2010; da Silva et al., 2012).

$$
\begin{aligned}
& \text { HREEs } \left.-\mathrm{PO}_{4(\mathrm{~s})}+3 \mathrm{NaOH}_{(\mathrm{s})} \rightarrow \mathrm{HREEs} \mathrm{OH}\right)_{3(\mathrm{~s})}+\mathrm{Na}_{3} \mathrm{PO}_{4(\mathrm{~s})} \\
& \mathrm{YPO}_{4}+3 \mathrm{NaOH} \rightarrow \mathrm{Y}(\mathrm{OH})_{3}+\mathrm{Na}_{3} \mathrm{PO}_{4} \\
& \mathrm{GdPO}_{4}+3 \mathrm{NaOH} \rightarrow \mathrm{Gd}(\mathrm{OH})_{3}+\mathrm{Na}_{3} \mathrm{PO}_{4} \\
& \mathrm{ErPO}_{4}+3 \mathrm{NaOH} \rightarrow \mathrm{Er}(\mathrm{OH})_{3}+\mathrm{Na}_{3} \mathrm{PO}_{4} \\
& \mathrm{DyPO}_{4}+3 \mathrm{NaOH} \rightarrow \mathrm{Dy}(\mathrm{OH})_{3}+\mathrm{Na}_{3} \mathrm{PO}_{4} \\
& \mathrm{YbPO}_{4}+3 \mathrm{NaOH} \rightarrow \mathrm{Yb}(\mathrm{OH})_{3}+\mathrm{Na}_{3} \mathrm{PO}_{4}
\end{aligned}
$$




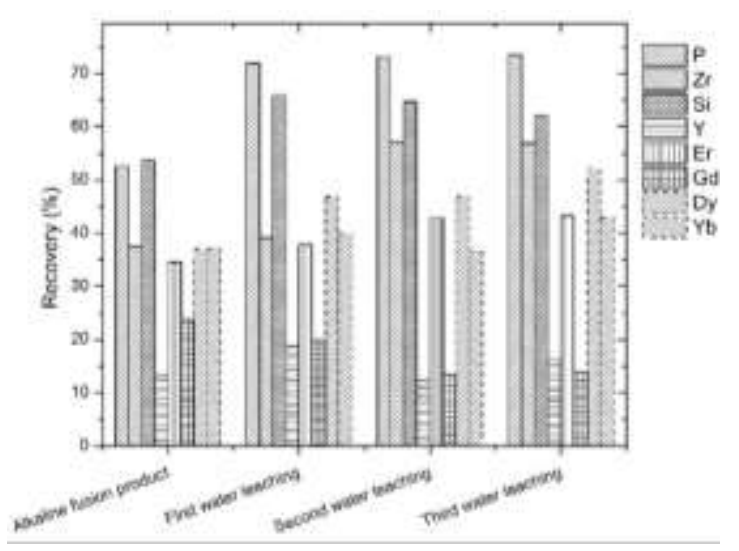

Figure 4 HREEs and major elements' recovery from alkaline fusion to the third water leaching

As Figure 4 shows, not only phosphates were recovered but also silica and zircon, which were the major elements in the sample. Most of the phosphate, silica, and zircon were separated-at 75\%, 66.45\%, and 60\%, respectively-during the alkaline fusion process. This separation implies that the alkaline fusion process is effective in separating unwanted major elements from the final product (dissolved during the water leaching process). The alkaline fusion process can also maximize the recovery of HREEs in the leaching process at a later stage, and solid products from alkaline fusion can be dissolved easily in acids, including sulfuric acid (Dai et al., 2014). However, some HREEs (Y, Gd, Er, Dy, and Yb) were found to have dissolved in the water leaching process. The recovery of yttrium, gadolinium, erbium, dysprosium, and ytterbium stood at 16.15\%, 13.78\%, 43.24\%, 52\%, and 42.94\%, respectively, after the third water leaching. Therefore, the recycling process is needed to extract the recovered HREEs in the filtrate from the alkaline fusion process.

\subsection{Leaching Process}

Acid leaching was carried out to dissolve HREEs from the solid products of the alkaline fusion process (Gupta and Krishnamurthy, 2005; Habashi, 1992). Several leaching conditions were observed in this experiment, such as acid concentration, temperature, and the solid-liquid ratio. Reactions that occur in the leaching process are shown in Equations 8-13 (Amer et al., 2013; Sadri et al., 2017).

$$
\begin{gathered}
2 \mathrm{HREEs}(\mathrm{OH})_{3}+3 \mathrm{H}_{2} \mathrm{SO}_{4} \rightarrow \mathrm{HREEs}_{2}\left(\mathrm{SO}_{4}\right)_{3}+6 \mathrm{H}_{2} \mathrm{O} \\
2 \mathrm{Y}(\mathrm{OH})_{3}+3 \mathrm{H}_{2} \mathrm{SO}_{4} \rightarrow \mathrm{Y}_{2}\left(\mathrm{SO}_{4}\right)_{3}+6 \mathrm{H}_{2} \mathrm{O} \\
2 \mathrm{Gd}(\mathrm{OH})_{3}+3 \mathrm{H}_{2} \mathrm{SO}_{4} \rightarrow \mathrm{Gd}_{2}\left(\mathrm{SO}_{4}\right)_{3}+6 \mathrm{H}_{2} \mathrm{O} \\
2 \mathrm{Er}(\mathrm{OH})_{3}+3 \mathrm{H}_{2} \mathrm{SO}_{4} \rightarrow \mathrm{Er}_{2}\left(\mathrm{SO}_{4}\right)_{3}+6 \mathrm{H}_{2} \mathrm{O} \\
2 \mathrm{Dy}(\mathrm{OH})_{3}+3 \mathrm{H}_{2} \mathrm{SO}_{4} \rightarrow \mathrm{Dy}_{2}\left(\mathrm{SO}_{4}\right)_{3}+6 \mathrm{H}_{2} \mathrm{O} \\
2 \mathrm{Yb}(\mathrm{OH})_{3}+3 \mathrm{H}_{2} \mathrm{SO}_{4} \rightarrow \mathrm{Yb}_{2}\left(\mathrm{SO}_{4}\right)_{3}+6 \mathrm{H}_{2} \mathrm{O}
\end{gathered}
$$

\subsubsection{Effect of $\mathrm{H}_{2} \underline{\mathrm{SO}}_{4}{ }_{4}$ concentration on HREEs recovery}

The recovery of HREEs increased with increasing concentrations of sulfuric acid. Furthermore, the recovery of HREEs significantly increased at concentrations of $0.125-0.5$ M. As Figure 5 shows, $83 \%$ of yttrium was recovered at $0.5 \mathrm{M}$ sulfuric acid. At the same concentration of sulfuric acid, more than $90 \%$ of the other HREEs were recovered, and even gadolinium had reached 99\% recovery. The reason for these results is that HREEs $(\mathrm{OH})_{3}$ are very soluble in acids-especially in strong acids, such as $\mathrm{H}_{2} \mathrm{SO}_{4}$ solution (Zhang and Saito, 1998). At higher acid concentrations, the increased recovery was not significant for all HREEs. This phenomenon is based on solvent concentrations being higher at greater densities. Therefore, the solution that reacted inside the particle was difficult to diffuse out, causing recovery not to increase again. Therefore, a concentration of $0.5 \mathrm{M}$ was chosen for 
the next process by varying the leaching temperature. HREEs recovery in this experiment slightly exceeded the recovery of deep-sea nodules, which stated that less than $70 \%$ of total REE was leached using $3 \mathrm{M} \mathrm{H}_{2} \mathrm{SO}_{4}$ for two hours at $30^{\circ} \mathrm{C}$ with $500 \mathrm{rpm}$ and a particle size of $75 \mu \mathrm{m}$ (Parhi et al., 2013). As reported by Kusrini et al. (2020), the optimum parameters for extraction of lanthanum from silica sand was obtained at the concentration of sulfuric acid of $3 \mathrm{M}$ and the acid volume of $250 \mathrm{~mL}$. Kim et al. (2009) also stated that $0.25 \mathrm{M} \mathrm{H}_{2} \mathrm{SO}_{4}$ can leach up to $80 \%$ of rare earth elements with a leaching time of 60 minutes at room temperature and a ratio of $1 \mathrm{~g} / 200 \mathrm{~mL}$ of acid.

\subsubsection{Effect of temperature on HREEs recovery}

The leaching-process temperature was varied in the range of $30-110^{\circ} \mathrm{C}$, while other parameters were fixed (a $0.5 \mathrm{M} \mathrm{H}_{2} \mathrm{SO}_{4}$ solution, an S/L ratio of $5 \mathrm{~g} / 50 \mathrm{~mL}, 150 \mathrm{rpm}$, and 60 minutes), and the results are shown in Figure 6. The recovery of HREEs did not increase if temperatures rose from $30^{\circ} \mathrm{C}$ to $40^{\circ} \mathrm{C}$ due to a slight increase in temperature not providing a significant increase in recovery over a long leaching duration. For the recovery of elements that were relatively insensitive to temperature, the activation energy is generally low and more likely to result from a diffusion-controlled process (Yang, 2019). However, the increase in HREEs recovery was seen to be significant at $60^{\circ} \mathrm{C}$. As much as $89 \%, 99 \%$, $96 \%, 92 \%$, and $90 \%$ of HREEs were covered at $60^{\circ} \mathrm{C}$ for $\mathrm{Y}_{2} \mathrm{O}_{3}, \mathrm{Gd}_{2} \mathrm{O}_{3}, \mathrm{Er}_{2} \mathrm{O}_{3}, \mathrm{Dy}_{2} \mathrm{O}_{3}$, and $\mathrm{Yb}_{2} \mathrm{O}_{3}$, respectively. Ariuntuya (2018) and Guo et al. (2018) also mentioned that the recovery increase was not significant when the leaching temperature was varied in the specified leaching duration with as much as $90 \%$ and $87 \%$ of HREEs recovered from REHs for rare earth concentrates in Bayan Obo and apatite in Japan.

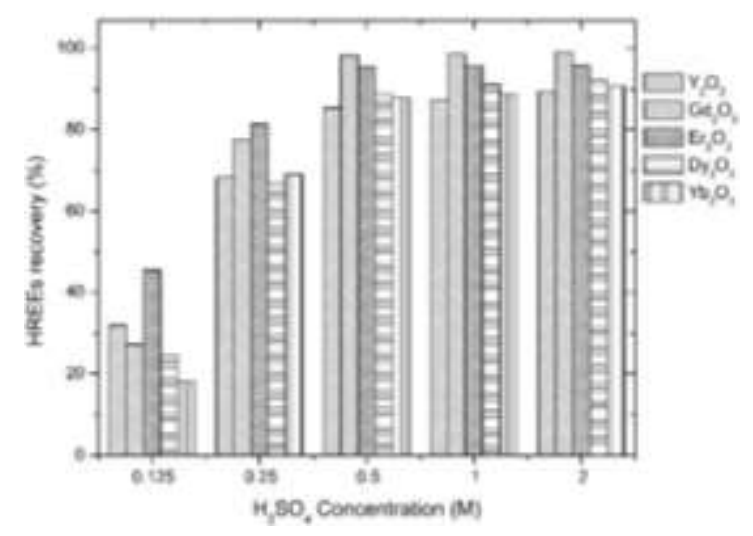

Figure 5 Effect of $\mathrm{H}_{2} \mathrm{SO}_{4}$ concentration on HREEs recovery $\left(80^{\circ} \mathrm{C}, 5 \mathrm{~g} / 50 \mathrm{~mL}, 150 \mathrm{rpm}\right.$, and $60 \mathrm{~min})$

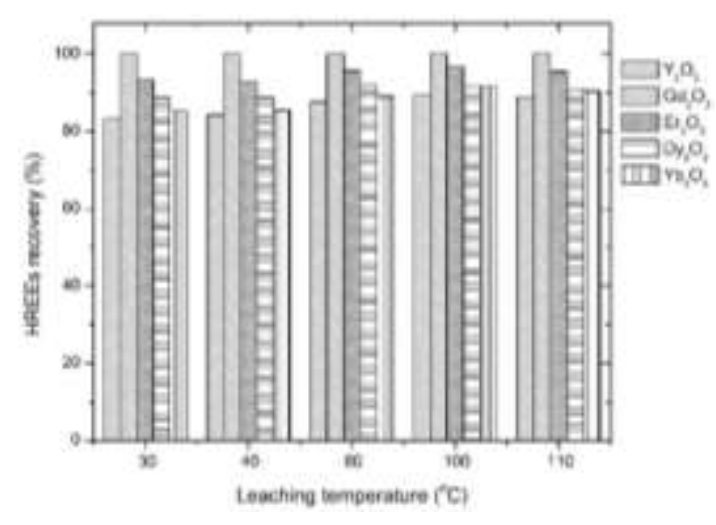

Figure 6 Effect of leaching temperature on HREEs recovery $\left(0.5 \mathrm{M} \mathrm{H}_{2} \mathrm{SO}_{4}, 5 \mathrm{~g} / 50 \mathrm{~mL}\right.$, $150 \mathrm{rpm}$, and $60 \mathrm{~min})$

The reaction between REE- $(\mathrm{OH})_{3}$ and sulfuric acid is exothermic (Panda et al., 2014), which was evidenced by a rise in temperature just after mixing. Chen et al. (2018) and Stopic et al. (2018) also said that the reaction was exothermic - and that the leaching process at higher than $90^{\circ} \mathrm{C}$ would not result in a better recovery of HREE. At higher temperatures, the recovery of HREEs tends not to show an increase. Because leaching reactions are exothermic, if the temperature is too high, the reaction may proceed in the opposite direction (Panda et al., 2014). Therefore, the temperature of $60^{\circ} \mathrm{C}$ was chosen as the leaching temperature and used as the optimum condition in observing the effect of the $\mathrm{S} / \mathrm{L}$ ratio on the recovery of HREEs.

\subsubsection{Effect of S/L ratio on HREEs recovery}

Figure 7 shows the effects of the S/L ratio on HREEs recovery. This experiment was performed with various ratios, while other leaching conditions were fixed, including the 0.5 
$\mathrm{M} \mathrm{H}_{2} \mathrm{SO}_{4}$ solution, $60^{\circ} \mathrm{C}, 150 \mathrm{rpm}$, and 60 minutes. Recoveries of HREEs decreased with an increasing $\mathrm{S} / \mathrm{L}$ ratio. It is well known that a lower $\mathrm{S} / \mathrm{L}$ ratio can reduce the viscosity of slurry to improve the mass transfer rate between solid and liquid (Huang et al., 2017). The most significant decrease in recovery was indicated by gadolinium $\left(\mathrm{Gd}_{2} \mathrm{O}_{3}\right)$, as $99 \%$ was recovered at an $\mathrm{S} / \mathrm{L}$ ratio of $10 \mathrm{~g} / 100 \mathrm{~mL}$, which decreased to $28 \%$ at $25 \mathrm{~g} / 100 \mathrm{~mL}$. Cumulatively, a decrease of $10 \mathrm{~g} / 100 \mathrm{~mL}$ was recorded, which was not significant in the range of $5 \mathrm{~g} / 100 \mathrm{~mL}$ to $10 \mathrm{~g} / 100 \mathrm{~mL}$. Alkan et al. (2018) and Li et al. (2013) also reported a decrease in leaching recovery when the S/L ratio increases; one is a study on rare earth concentrate leaching that found the $\mathrm{S} / \mathrm{L}$ ratio to have a negative effect when the ratio was higher than $100 \mathrm{~g} / \mathrm{L}$. Therefore, the S/L ratio of $10 \mathrm{~g} / 100 \mathrm{~mL}$ was selected as the optimum ratio, based on the amount of acid solution consumption.

\subsection{XRD Analysis}

$\mathrm{XRD}$ analysis was performed to confirm the occurrence of phase transformation during the leaching process. Samples C1 and C5 represent the residual leaching process with the lowest and highest recoveries of all REEs. Figure 8 compares the XRD patterns of the three samples.

Zircon and quartz did not decompose into sodium zirconate and sodium silicate during the alkaline fusion process because the temperatures only reached $450^{\circ} \mathrm{C}$. The minerals are known to decompose with good recovery only at $550^{\circ} \mathrm{C}$ and above (Beyer et al., 1954; da Silva et al., 2012). Biswas et al. (2010), Van Tuyen et al. (2007), and Song et al. (2015) mentioned that the optimized alkaline fusion zircon conditions are $700^{\circ} \mathrm{C}$, which was further confirmed by the XRD pattern of the three samples (Figure 8). During the alkaline fusion process, monazite and xenotime decomposed into REEs-hydroxide, followed by further dissolution into REEs $-\left(\mathrm{SO}_{4}\right)_{3}$ at the leaching phase. Under maximum leaching conditions, HREEs were not detected in the residues, indicating that HREEs easily dissolved in strong acidic conditions (Panda et al., 2014; Borai et al., 2016; Suli et al., 2017).

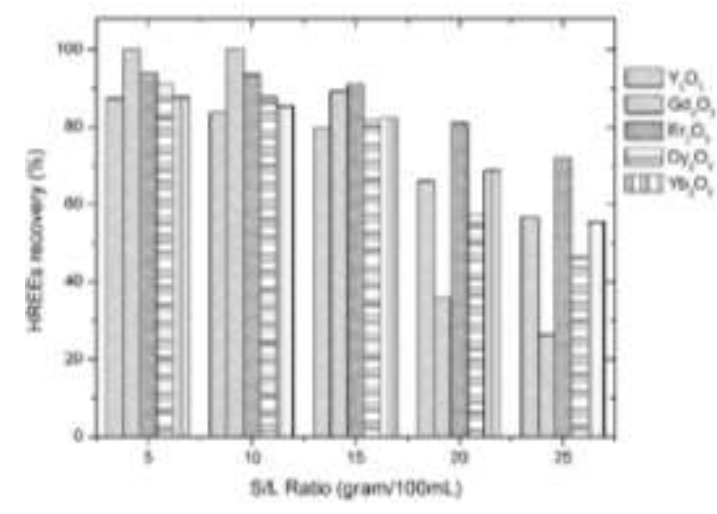

Figure 7 Effect of S/L ratio on HREEs recovery $\left(60^{\circ} \mathrm{C}, 0.5 \mathrm{M} \mathrm{H}_{2} \mathrm{SO}_{4}, 150 \mathrm{rpm}\right.$, and $60 \mathrm{~min}$ )

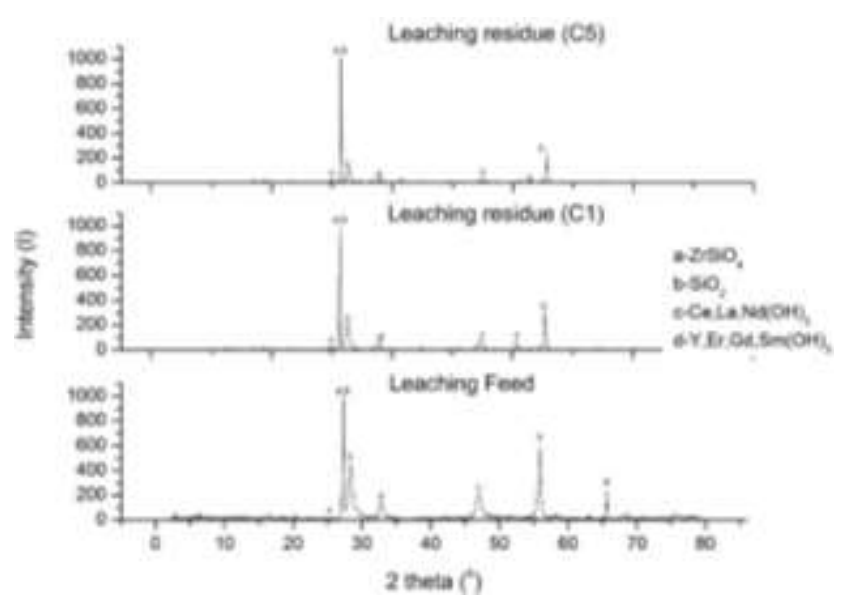

Figure 8 XRD pattern for leaching feed, C1, and C5 samples

\section{Conclusions}

The process of leaching HREEs was investigated through several parameters, and the optimum conditions were identified. Sample characterization was carried out through the process of sieving and analyzing the composition of the sample using XRF. The pretreatment process was carried out to increase the recovery of HREEs. The pretreatment process includes alkaline fusion and leaching using deionized water. The alkaline fusion 
process of tailing zircon was completed in three hours at a temperature of $450^{\circ} \mathrm{C}$ and tailings at an $\mathrm{NaOH}$ ratio of $1: 1$ (wt/wt). In addition, recovery phosphate increased following the pretreatment processes of alkaline fusion, characterized by a $73.57 \%$ reduction in phosphate binding to HREEs, followed by the leaching process performed to dissolve HREEs- $(\mathrm{OH})_{3}$ into a solution of HREEs ${ }_{2}-\left(\mathrm{SO}_{4}\right)_{3}$. The optimum leaching conditions in this experiment occurred at concentrations of $2 \mathrm{M} \mathrm{H}_{2} \mathrm{SO}_{4}, 60^{\circ} \mathrm{C}$, an S/L ratio of $10 \mathrm{~g} / 100$ $\mathrm{mL}$, and $150 \mathrm{rpm}$ during 60 minutes. Under these conditions, HREEs were recovered at as much as $89 \%, 99 \%, 94 \%, 92 \%$, and $90 \%$ for Y, Gd, Er, Dy, and Yb, respectively. This experiment is expected to serve as a treatment solution for tailings from zircon sand mining activities and as an alternative solution for processing HREEs from secondary sources.

\section{Acknowledgements}

The authors are grateful to Universitas Gadjah Mada for supporting this research and also to PSTA-BATAN, Indonesia, for the analytical instruments used to complete this study. In addition, one of the authors, Iga Trisnawati, appreciates financial support from Beasiswa Saintek Kemenristek/BRIN.

\section{References}

Alkan, G., Yagmurlu, B., Cakmakoglu, S., Hertel, T., Kaya, Ş., Gronen, L., Stopic, S., Friedrich, B., 2018. Novel Approach for Enhanced Scandium and Titanium Leaching Efficiency from Bauxite Residue with Suppressed Silica Gel Formation. Scientific Reports, Volume 8(1), pp. 1-11

Amer, T.E., Abdella, W.M., Wahab, G.M.A., El-Sheikh, E.M., 2013. A Suggested Alternative Procedure for Processing of Monazite Mineral Concentrate. International Journal of Mineral Processing, Volume 125, pp. 106-111

Ariuntuya, B., 2018. Recovery of Rare Earth Elements from Apatite Ores by Hydrometallurgical Process, Akita University, pp. 61-63

Aznar-Sánchez, J.A., García-Gómez, J.J., Velasco-Muñoz, J.F., Carretero-Gómez, A., 2018. Mining Waste and its Sustainable Management: Advances in Worldwide Research. Minerals, Volume 8(7), pp. 1-27

Beyer, G.H., Spink, D.R., West, J.B., Wilhelm, H.A., 1954. Caustic Treatment of Zircon Sand, Ames Laboratory ISC Technical Reports. 66, pp. 1-15

Biswas, R.K., Habib, M.A., Karmakar, A.K., Islam, M.R., 2010. A Novel Method for Processing of Bangladeshi Zircon: Part I: Baking, and Fusion with NaOH. Hydrometallurgy, Volume 103(1-4), pp. 124-129

Borai, E.H., El-ghany, M.S.A., Ahmed, I.M., Hamed, M.M., El-din, A.M.S., Aly, H.F., 2016. Modified Acidic Leaching for Selective Separation of Thorium, Phosphate and Rare Earth Concentrates from Egyptian Crude Monazite. International Journal of Mineral Processing, Volume 149, pp. 34-41

Brückner, L., Elwert, T., Schirmer, T., 2020. Extraction of Rare Earth Elements from Phospho-Gypsum: Concentrate Digestion, Leaching, and Purification. Metals, Volume 10(1), pp. 1-21

Chen, K., Pei, J., Yin, S., Li, S., Peng, J., Zhang, L., 2018. Leaching Behaviour of Rare Earth Elements from Low-grade Weathered Crust Elution-deposited Rare Earth or using Magnesium Sulfate. Clay Minerals, Volume 53(3), pp. 505-514

da Silva, R.J.F., Dutra, A.J.B., Afonso, J.C., 2012. Alkali Fusion Followed by a Two-step Leaching of a Brazilian Zircon Concentrate. Hydrometallurgy, Volume 117-118, pp. 93100 
Dai, S., Seredin, V.V., Ward, C.R., Jiang, J., Hower, J.C., Song, X., Jiang, Y., Wang, X., Gornostaeva, T., Li, X., Liu, H., Zhao, L., Zhao, C., 2014. Composition and Modes of Occurrence of Minerals and Elements in Coal Combustion Products Derived from High-Ge Coals. International Journal of Coal Geology, Volume 121, pp. 79-97

Durucan, S., Korre, A., Munoz-Melendez, G., 2006. Mining Life Cycle Modelling: A Cradle-ToGate Approach to Environmental Management in the Minerals Industry. Journal of Cleaner Production, Volume 14(12-13 SPEC. ISS.), pp. 1057-1070

Eduafo, P.M., 2013. Experimental Investigation of Recycling Rare Earth Elements from Waste Fluorescent Lamp Phosphors, pp. 85

El Hady, S.M., Bakry, A.R., Al Shami, A.A.S., Fawzy, M.M., 2016. Processing of the Xenotime Concentrate of Southwestern Sinai via Alkali Fusion and Solvent Extraction. Hydrometallurgy, Volume 163, pp. 115-119

Febriana, E., Tristiyan, A., Mayangsari, W., Prasetyo, A.B., 2018. Kinetika dan Mekanisme Pelindian Nikel dari Bijih Limonit: Pengaruh Waktu dan Temperatur. Metalurgi, Volume 2, pp. 61-68

Gambogi, J., 2019. Mineral Commodity Summaries 2019. Virginia: U.S. Geological Survey, Department of the Interior, pp. 132

Guo, W.L., Cang, D.Q., Xu, Y.H., Ma, S.F., Tian, H., Meng, Z. J., Zhang, X.X., 2018. Study on Alkali Liquor Roasting and Sulphuric Acid Leaching of Bayan Obo Rare Earth Concentrate. Metalurgija, Volume 57(3), pp. 157-161

Gupta, C.K., Krishnamurthy, N., 2005. Extractive Metallurgy of Rare Earths. $1^{\text {st }}$ edition, Mumbai: CRC Press, pp. 100-105

Habashi, F., 1992. Extractive Metallurgy of Rare Earths. International Materials Reviews, Volume 37(1), pp. 197-248

Hamzah, Y., Mardhiansyah, M., Firdaus, L.N., 2018. Characterization of Rare Earth Elements in Tailing of Ex-Tin Mining Sands from Singkep Island, Indonesia. Aceh International Journal of Science and Technology, Volume 7(2), pp. 131-137

Handoko, A.D., Sanjaya, E., 2018. Characteristics and Genesis of Rare Earth Element (REE) in Western Indonesia. In: IOP Conference Series: Earth and Environmental Science, Volume 118, pp. 1-5

Harjanto, S., Virdhian, S., Afrilinda, E., 2013. Characterization of Indonesia Rare Earth Minerals and Their Potential Processing Techniques. Rare Earth, Volume 52, pp. 99108

Haxel, G.B., Hedrick, J.B., Orris, G.J., 2014. Rare Earth Elements - Critical Resources for High Technology. Virginia: U.S. Geological Survey, pp. 2014-2015

Huang, Y., Dou, Z., Zhang, T. an, Liu, J., 2017. Leaching Kinetics of Rare Earth Elements and Fluoride from Mixed Rare Earth Concentrate After Roasting with Calcium Hydroxide and Sodium Hydroxide. Hydrometallurgy, Volume 173, pp. 15-21

Hudson-Edwards, K.A., Dold, B., 2015. Mine Waste Characterization, Management and Remediation. Minerals, Volume 5(1), pp. 82-85

Kim, W., Bae, I., Chae, S., Shin, H., 2009. Mechanochemical Decomposition of Monazite to Assist the Extraction of Rare Earth Elements. Journal of Alloys and Compounds, Volume 486(1-2), pp. 610-614

King, H.M., 2013. REE - Rare Earth Elements and their Uses. Available Online at https://geology.com/articles/rare-earth-elements/

Kumari, A., Panda, R., Jha, M.K., Lee, J.Y., Kumar, J.R., Kumar, V., 2015. Thermal Treatment for the Separation of Phosphate and Recovery of Rare Earth Metals (REMs) from Korean Monazite. Journal of Industrial and Engineering Chemistry, Volume 21, pp. 696703 
Kusrini, E., Utami, C., Usman, A., Nasruddin, N., Tito, K., 2018a. $\mathrm{CO}_{2}$ Capture using Graphite Waste Composites and Ceria. International Journal of Technology, Volume 9(2), pp. 287-296

Kusrini, E., Kinastiti, D.D., Wilson, L., Usman, A., Rahman, A., 2018b. Adsorption of Lanthanide Ions from Aqueous Solution in Multicomponent Systems using Activated Carbon from Banana Peels (Musa paradisiaca L.). International Journal of Technology, Volume 9(6), pp. 1132-1139

Kusrini, E., Zulys, A., Rachmana, A., Aprillia Wulandari, D., Muharam, Y., Usman, A., Rahman, A., 2020. Enrichment and Extraction of Lanthanum from Belitung Silica Sand using Sulfuric Acid Heap Leaching, Precipitation and Complexation with Phytic Acid. In: Materials Today: Proceedings

Li, M., Zhang, X., Liu, Z., Hu, Y., Wang, M., Liu, J., Yang, J., 2013. Kinetics of Leaching Fluoride from Mixed Rare Earth Concentrate with Hydrochloric Acid and Aluminum Chloride. Hydrometallurgy, Volume 140, pp. 71-76

Lide, D.R., 2004. CRC Handbook of Chemistry and Physics. 85 ${ }^{\text {th }}$ Edition, G. Baysinger, L.I. Berger, R.N.G. Goldberg, H.V.Kehiaian, and K. Kuchitsu, Edition, New York: CRC Press, Volume 268, pp. 14.10-14.14

Machmudah, S., Ceaser, M.R., Alwajdy, M.F., Widiyastuti, W., Winardi, S., Wahyudiono, W., Kanda, H., Goto, M., 2019. Hydrothermal and Solvothermal Synthesis of CeriumZirconium Oxides for Catalyst Applications. International Journal of Technology, Volume 10(3), pp. 582-592

Panda, R., Kumari, A., Jha, M.K., Hait, J., Kumar, V., Rajesh Kumar, J., Lee, J.Y., 2014. Leaching of Rare Earth Metals (REMs) from Korean Monazite Concentrate. Journal of Industrial and Engineering Chemistry, Volume 20(4), pp. 2035-2042

Parhi, P.K., Park, J.T., Park, K.H., Nam, C.W., Barik, S.P., 2013. Extraction of Rare Earth Metals from Deep Sea Nodule using $\mathrm{H}_{2} \mathrm{SO}_{4}$ Solution. International Journal of Mineral Processing, Volume 119, pp. 89-92

Prameswara, G., Mulyono, P., Prasetya, A., Poernomo, H., Trisnawati, I., 2019. Ekstraksi Logam Tanah Jarang (LTJ) dan Logam Berharga Hasil Fusi Alkali Tailing Zirkon. Seminar Teknik Kimia Kejuangan, 1-7

Prameswara, G., Trisnawati, I., Poernomo, H., Mulyono, P., Prasetya, A., Petrus, H.T.B.M., 2020. Kinetics of Yttrium Dissolution from Alkaline Fusion on Zircon Tailings. Mining, Metallurgy and Exploration, Volume 37, pp. 1297-1305

Priyono, S., Febrianto, E.Y., 2012. Pemurnian Serbuk Zirkonia dari Zirkon. Jurnal Ilmu Pengetahuan dan Teknologi, Volume 30(1), pp. 1-6

Qi, D., 2018. Extraction of Rare Earths from RE Concentrates. Hydrometallurgy of Rare Earths, Amsterdam: Elsevier, pp. 1-185

Reichl, C., Schatz, M., Zsak, G., 2018. World Mining Data 2018 Iron and Ferro Alloy Metals Non-Ferrous, Metals Precious Metals, Industrial Minerals, and Mineral Fuels. World Mining Data 2018, International Organizing Committee for the World Mining Congress, Vienna, 263

Sadri, F., Nazari, A.M., Ghahreman, A., 2017. A Review on the Cracking, Baking and Leaching Processes of Rare Earth Element Concentrates. Journal of Rare Earths, Volume 35(8), pp. 739-752

Song, J., Fan, J.F., Liu, J.C., Liu, R., Qu, J.K., Qi, T., 2015. A Two-step Zircon Decomposition Method to Produce Zirconium Oxychloride: Alkali Fusion and Water Leaching. Rare Metals, Volume 39, pp. 448-454

Stopic, S., Friedrich, B., 2018. Leaching of Rare Earth Elements with Sulfuric Acid from Bastnasite Ores. Vojnotehnicki Glasnik, Volume 66(4), pp. 757-770 
Suli, L.M., Ibrahim, W.H.W., Aziz, B.A., Deraman, M.R., Ismail, N.A., 2017. A Review of Rare Earth Mineral Processing Technology. Chemical Engineering Research Bulletin, Volume 19(2017), pp. 20-35

Tang, M., Zhou, C., Pan, J., Zhang, N., Liu, C., Cao, S., Hu, T., Ji, W., 2019. Study on Extraction of Rare Earth Elements from Coal Fly Ash Through Alkali Fusion - Acid Leaching. Minerals Engineering, Volume 136, pp. 36-42

Trinopiawan, K., Mubarok, M.Z., Mellawati, J., Ani, B.Y., 2016. Pelindian Logam Tanah Jarang dari Terak Timah dengan Asam Klorida setelah Proses Fusi Alkali. Eksplorium, Volume 37(1), pp. 41-50

Van Tuyen, N., Thanh Quang, V., Giang Huong, T., Huu Anh, V., 2007. Preparation of High Quality Zirconium Oxychloride from Zircon of Vietnam. The Anual Report for 2007, VAEC-AR 07--43, pp. 286-291

Yang, X., 2019. Leaching Characteristics of Rare Earth Elements from Bituminous Coal-based Sources, pp. 159

Yang, X., Satur, J.V., Sanematsu, K., Laukkanen, J., Saastamoinen, T., 2015. Beneficiation Studies of a Complex REE Ore. Minerals Engineering, Volume 71, pp. 55-64

Zhang, Q., Saito, F., 1998. Non-thermal Process for Extracting Rare Earths from Bastnaesite by Means of Mechanochemical Treatment. Hydrometallurgy, Volume 47(2-3), pp. 231241 